\title{
Effect of a caffeinated energy drink and its withdrawal on the submandibular salivary gland of adult male albino rats: A histological and immunohistochemical study
}

Original Article
Amira A. Kassab, MD, and Sadika M Tawfik, MD

Department of Histology, Faculty of Medicine, Tanta University, Tanta, Egypt

\begin{abstract}
Introduction: Energy drinks provide the consumer witha combination of stimulants and energy boosters that increases the physical endurance, concentration, muscular performance and mood. Despite their benefits, many health hazards occur that may be attributed to its caffeine content.

Aim: To study the effect of a caffeinated energy drink on the histological structure of submandibular salivary gland of albino rats and evaluation of the effect of its withdrawal.

Materials and Methods: Thirty adult male albino rats were divided into 3 equal groups: control group, group II (received the energy drink in a dose $3.75 \mathrm{ml} / \mathrm{Kg}$ daily orally for 8 weeks), group III (received the energy drink in a dose $3.75 \mathrm{ml} / \mathrm{Kg}$ daily orally for 8 weeks, and left for another 8 weeks without treatment). The submandibular salivary gland specimens were taken and prepared for light and electron microscopic study and immunohistochemical staining for myoepithelial cells using anti $\alpha$-SMA antibody.

Results: Specimens from group II showed disturbance of the normal structure of the submandibular salivary glands. The lining epithelium of the acini and ducts showed cytoplasmic vacuoles with compressed or pyknotic nuclei. Disturbance of the basal striation of the cells lining striated ducts. There was deposition of abundant collagen fibers between the lobules and around the acini and ducts. A statistically highly significant increase in $\alpha$-SMA immunoreaction was noticed around the acini, intercalated, striated and granular ducts. Ultrastructurally, fusion of the secretory granules, swollen mitochondria, dilatation and fragmentation of rough endoplasmic reticulum of the acinar cells were observed. Amelioration of the previous histological changes was detected in group III after withdrawal of the caffeinated energy drink.

Conclusion: The caffeinated energy drink induced structural changes in the submandibular salivary gland of Albino rats which were partially ameliorated by its withdrawal. So, excessive intake of the caffeinated energy drinks should be considered as health hazard for human.
\end{abstract}

Received: 11 January 2018, Accepted: 12 February 2018

Key Words: : Energy drink, myoepithelium, submandibular salivary gland.

Corresponding Author: Amira Adly Kassab, M.D., Department of Histology, Faculty of Medicine, Tanta University, Tanta, Egypt, Tel.: 0020106697635, E-mail: Amirakassab80@yahoo.com.

ISSN: 1110-0559, Vol. 41, No.1

\section{INTRODUCTION}

Salivary glands secrete saliva which plays a vital role in maintaining general health of the oral cavity. Deficient salivary secretions may lead to many health problems as recurrent dental caries, mucosal infection, disturbed taste perception and difficulty in swallowing and speaking. These problems lead to many psychological disturbances in the form of recurrent stress and depression ${ }^{[1-3]}$.

The submandibular salivary glands are major salivary glands situated at some distance from the oral epithelium and are connected to it by the main excretory duct. Histologically, they are formed of a branching system of ducts that has clusters of glandular acini at its ends. The granular duct (granular convoluted tubule, GCT) is located between the intercalated duct (ID) and striated duct (SD) in the rodent submandibular salivary gland. The granular duct is lined by a simple columnar epithelium. The principal cell type of the GCT is a high-columnar secretory cell containing many secretory granules in its supranuclear cytoplasm. These granules contain a variety of biologically active polypeptides such as cell growth factors and hormones that are secreted in response to neural and hormonal stimuli ${ }^{[4,5]}$.

The myoepithelial cells surround the acini and intercalated ducts in rat and human submandibular salivary gland. One myoepithelial cell is usually found around each secretory end piece between the basement membrane and the basal plasma membrane of the cells. They squeeze the acini to help the secretion. Moreover, they synthesize 
growth factors for the health of the gland epithelium and support their growth ${ }^{[5-7]}$. The myoepithelial cells have features of both epithelial and smooth muscle cells. Alpha smooth muscle actin ( $\alpha$-SMA) is a specific marker for smooth muscle cells and is expressed by myoepithelial cells. So, it is used for their identification ${ }^{[8,9]}$.

Energy drinks are available worldwide. They contain caffeine, L-carnitine, carbohydrates, glucuronolactone, vitamins and herbal supplements ${ }^{[10]}$. Different brands of energy drinks contain 50-550 mg caffeine per can. They are consumed in large doses by athletes, teenagers and college students to increase their energy level and compensate the lack of sleep. They may improve mood, enhance physical performance and reduce mental fatigue ${ }^{[11,12]}$. In spite of this, it was reported that massive consumption of all energy drinks may lead to severe life-threatening diseases ${ }^{[13-15]}$.

Noteworthy, the ingestion of the caffeinated energy drinks usually associates with several side effects such as insomnia, nervousness, restlessness, gastric irritation, nausea, vomiting, tachycardia, tremors and anxiety ${ }^{[16,17]}$. Moreover, many cardiovascular health problems as well as increased risks of diabetic complications had been reported ${ }^{[18,19]}$. Previous studies proved that energy drinks had many harmful effects on the kidney, liver and cardiac muscle $^{[20-22]}$.

As the consumption of energy drinks continues to increase, it is necessary to consider their potential side effects. Therefore, the present work aimed to study the effect of a caffeinated energy drink on the histological structure of submandibular salivary gland of adult male Albino rats, besides, evaluating the effect of its withdrawal.

\section{MATERIALS AND METHODS}

\section{Caffeinated energy drink}

Red Bull cans (250 ml) [Red Bull GmbH, 5330Fuschl am See, Austria] were purchased from a local market in Tanta city (Egypt). Each $100 \mathrm{ml}$ of the Red Bull contains caffeine $(0.03 \%)$, taurine $(0.4 \%)$, gluconolactone $(0.24 \%)$, niacin $(8 \mathrm{mg})$, vitamin B6 (2 mg), B12 (0.002 mg), pantothenic acid $(2 \mathrm{mg})$ together with a mixture of water, glucose, sucrose, sodium citrate, carbon dioxide, inositol, riboflavin, caramel, natural and artificial flavoring and coloring agents.

\section{Study design}

Thirty adult male Albino rats (200-250 grams) were kept in clean cages under the same environmental conditions and provided with a standard laboratory diet and water. Animals were allowed to adjust to the laboratory conditions two weeks before the experiment. The experiment protocol was approved by the Local Ethics Committee of Tanta Faculty of Medicine, Tanta University, Egypt.
The rats were equally divided into three groups: Group I (Control group): rats were left untreated. Group II (Energy drink "Red Bull" group): rats received the energy drink "Red Bull" at a dose of $3.75 \mathrm{ml} / \mathrm{kg} /$ day orally using gastric tube for eight consecutive weeks ${ }^{[23]}$. This dose $(3.75 \mathrm{ml})$ contains $1.13 \mathrm{mg}$ caffeine. Group III (withdrawal group): rats received the aforementioned dose of energy drink for the same period, thereafter rats were left for another eight weeks without any treatment.

\section{Histological techniques}

At the end of the experiment, all rats were anesthetized with intraperitoneal injection of sodium pentobarbital $(50 \mathrm{mg} / \mathrm{kg})^{[24]}$. The skin of the neck was incised, and the submandibular salivary glands were dissected out. Specimens from both glands were preserved in the fixatives and processed for histological study.

\section{Light microscopic examination}

Specimens of the submandibular salivary gland were fixed in $10 \%$ neutral-buffered formalin, dehydrated in ascending grades of alcohol, cleared in xylene and embedded in soft paraffin. Sections of $5 \mu \mathrm{m}$ thickness were cut and stained with hematoxylin and eosin (H\&E) as well as Mallory's trichrome stain to assess the degree of the gland fibrosis and immunohistochemical staining for $\alpha-\mathrm{SMA}^{[25]}$.

\section{Immunohistochemistry for Alfa-smooth muscle $\operatorname{actin}(\alpha-S M A)$}

Sections were first deparaffinized, rehydrated and washed three times with phosphate buffered saline (PBS). The sections were incubated with the primary antibody (mouse monoclonal antibody to $\alpha$-SMA, 1/500 dilution, clone 1A4, ab7817, Abcam) in a humid chamber overnight and then washed three times with PBS. Thereafter, these sections were incubated with the corresponding biotinylated peroxidase conjugated secondary antibody for one hour then rinsed three times in PBS. 3, 3'diaminobenzidine (DAB)-hydrogen peroxide was used as a chromogen to stain $\alpha$-SMA bounded structures and to localize the site of immunoreaction. Finally, the immunostained sections were counterstained by using Mayer's haematoxylin. For negative control sections, the primary antibody was replaced by normal serum ${ }^{[26]}$. The positive control was FFPE human breast ductal carcinoma.

\section{Electron microscope study}

Small specimens of the gland tissue were fixed in $2.5 \%$ phosphate buffered glutaraldehyde solution, washed in PBS, and post fixed in phosphate-buffered 1\% osmium tetroxide. The samples were rinsed in buffer, dehydrated in ascending grades of alcohol, and cleared in acetone. The samples were transferred into flat molds and then embedded in epoxy resin. Semithin sections $(1 \mu \mathrm{m}$ thick $)$ were cut, stained with $1 \%$ toluidine blue, and examined to select the suitable areas for ultrathin sections $(75-90 \mathrm{~nm})$, which were double stained with $8 \%$ uranyle acetate followed by 
lead citrate. The grids were examined and photographed using a JEOL transmission electron microscope at the Electron Microscope Units, at Tanta Faculty of Medicine and Mansoura Faculty of Agriculture ${ }^{[27]}$.

\section{Quantitative morphometric measurements}

The image analysis was performed (Leica Q $500 \mathrm{MC}$ program) at the Central Research Lab, Tanta Faculty of Medicine, Tanta University to measure the following parameters "in 10 different fields from each specimen":

1- The area percentage (\%) of collagen fibers (Mallory trichrome stain).

2- The color intensity of $\alpha$-SMA positive immunoreaction.

\section{Statistical Analysis}

One-way analysis of variance (ANOVA) followed by Tukey's procedure were used for data analysis and for comparison between the different groups using statistical package for social sciences statistical analysis software (version 11.5; SPSS Inc., Chicago, Illinois, USA). Mean \pm standard deviation were obtained. Probability values ( $P$-values) of $>0.05,<0.05$ and $<0.001$ were regarded non-significant, significant, and highly significant, respectively.

\section{RESULTS}

\section{Light Microscopic Results}

Examination of H\&E-stained sections obtained from the control group (group I) demonstrated the normal histological structure of the submandibular salivary gland. The gland was divided into numerous lobules separated by thin connective tissue septa which convey the blood vessels and interlobular excretory ducts. Each lobule contained closely packed serous acini as well as intralobular ducts (intercalated, striated and granular ducts) (Fig. 1). The acinar secretory cells appeared with darkly stained cytoplasm and rounded basophilic nuclei. The intercalated ducts were lined by simple cuboidal epithelium, whereas the striated ducts were lined by columnar cells having oval nuclei. The well-developed granular convoluted ducts were lined by high-columnar epithelial cells having acidophilic cytoplasm (Fig. 2). Toluidine blue-stained sections of control group showed acinar secretory cells with palestained granules filling the cytoplasm. Intercalated ducts, striated duct, and granular convoluted ducts were observed between the acini. The striated ducts showed characteristic basal striations. The granular convoluted ducts were identified by darkly-stained secretory granules in their apical cytoplasm. Myoepithelial cells surrounded the secretory acini and intercalated ducts (Figs. 3a and 3b).

Examination of Mallory trichrome-stained sections of control group revealed scanty collagen fibers in the connective tissue septa between the lobules surrounding the blood vessels and large excretory ducts (Fig. 4).
$\alpha$-SMA immuno-stained sections of control group showed weak positive immunoreaction in the cytoplasm of the myoepithelial cells around the acini and intercalated ducts, whereas negative reaction was noticed around the striated and granular ducts. Positive immunoreaction appeared in the wall of the blood vessels (Fig. 5).

In energy drink group (Group II), H\&E-stained sections revealed severe structural changes in the acini and ducts. The cytoplasm of the cells lining the secretory acini was vacuolated with small deeply stained or irregular nuclei compressed by their cytoplasmic vacuoles (Figs. 6 and $7 \mathrm{a}$ ). While, some acini were shrunken leaving spaces filled with infiltrating mononuclear cells (Figs. 7b and 9). The cells of the striated ducts showed cytoplasmic vacuoles and disturbed basal cell membrane (Fig. 6). Some granular ducts showed reduced acidophilic content of the cytoplasm while others were severely affected with destruction of their lining epithelial cells (Figs. 6 and 8). Mononuclear cellular infiltration and dilated congested blood vessels were seen in the interlobular connective tissue septa (Fig. 9). Some interlobular excretory ducts were dilated with cytoplasmic vacuolation of their lining epithelial cells, while others showed destruction of their lining epithelium (Fig. 10a). Stagnant secretion was observed in the lumen of some intralobular as well as interlobular ducts (Fig. 10b).

Examination of toluidine blue-stained sections confirmed the previous findings. The lining epithelium of some acini contained large cytoplasmic vacuoles compressing the nuclei. Deeply stained nuclei appeared in some cells and fragmented one was observed in others (Fig. 11). The lining cells of the striated ducts showed cytoplasmic vacuoles and accumulation of numerous lightly stained apical cytoplasmic granules. Other lining cells were severely affected and displayed small deeply stained nuclei as well as disturbed basal cell membrane striation. Moreover, myoepithelial cells appeared around the striated ducts. Few cytoplasmic vacuoles were seen in the lining cells of intercalated ducts (Figs. 11 and 12).

Mallory trichrome-stained sections revealed deposition of abundant collagen fibers in the connective tissue septa between the lobules that extended to surround the intralobular secretory acini and ducts (Fig. 13).

Concerning $\alpha$-SMA immunoreaction, a strong positive immunoreaction was noticed around the acini (Fig. 14), intercalated duct, striated ducts and granular convoluted ducts (Figs. 15a and 15b).

In the withdrawal group (Group III), examination of H\&E-stained sections revealed improvement of the histological structure. Many intralobular acini and ducts were more or less as control group with few infiltrating mononuclear cells (Fig. 16). Nevertheless, cytoplasmic vacuoles in few acinar cells as well as reduced acidophilic content of few granular duct cells were observed (Fig. 17). Regarding toluidine blue-stained sections, few cytoplasmic 
vacuoles were detected in few acinar and ductal cells (Fig. 18).

In addition, few collagen fibers were seen in connective tissue septa between the lobules and around the intralobular acini and ducts (Fig. 19).

Considering $\alpha$-SMA immunoreaction, there was a moderate positive immunoreaction around the acini and intralobular ducts (Fig. 20).

\section{Electron Microscopic Results}

In control group (Group I), examination of ultrathin sections revealed normal ultrastructure of the acini and ducts. The acinar cells were characterized by numerous electron lucent secretory granules filling the cytoplasm. Moreover, their basal cytoplasm contained rounded nuclei, packed parallel cisternae of rough endoplasmic reticulum (RER) in the vicinity of the nuclei and many mitochondria (Figs. $21 \mathrm{a}$ and b). The intercalated ducts were lined by simple cubical epithelial cells surrounding central regular rounded lumen and were embraced by myoepithelial cells (Fig. 21c). The lining cells of the striated ducts exhibited numerous mitochondria incorporated within the basal cell membrane infoldings in addition to the presence of small electron lucent vesicles in their apical cytoplasm (Fig. 21d).

In energy drink group (Group II), ultrathin sections showed variable degrees of affection of the acinar cells. The secretory granules of some acinar cells fused together and basally migrated. These large coalescent granules compressed and indented the nuclei (Fig. 22a). Some acinar cells showed swollen degenerated mitochondria (Fig. 22b). The rough endoplasmic reticulum were disorganized, apically dislocated, dilated and/or fragmented with dilated perinuclear space (Figs. 22 b, c and d). Some acinar cells were markedly affected with depletion of their cytoplasmic secretory granules and accumulation of lipid droplets and electron dense bodies in their cytoplasm. Other acinar cells appeared dark, shrunken with small irregular heterochromatic nuclei (Figs. 22 e and f). As regards intercalated ducts, partial separation of their lining cells from the basal lamina with widening of the intercellular spaces was noticed. The cytoplasm of some lining cells contained numerous electron dense bodies, lysosomes and Lipid droplets. The nuclei of some cells were small, irregular with peripheral heterochromatin (Figs. 23-a and b).

The striated ducts showed irregular lumen and were surrounded by myoepithelial cells (Fig. 24a). Some lining cells showed disturbed basal membrane infoldings and accumulated secretory granules in their apical cytoplasm (Figs. 24 b and c). Dark shrunken cells with small irregular heterochromatic nuclei were seen in some ducts (Fig. 24a)

Examination of ultrathin sections obtained from the withdrawal group (Group III) revealed amelioration of the ultrastructural changes induced by the caffeinated energy drink. Few acinar cells displayed depletion of their cytoplasmic granules. Others showed few large coalescent granules compressing the nucleus (Fig 25a). Abnormally divided nuclei were seen in some acinar cells (Fig. 25b). Intercalated ducts showed focal separation of the lining cells, mild widening of the intercellular space and few irregular nuclei with peripheral heterochromatin (Fig. 25c). Considering the striated ducts, most of their lining cells contained regular euchromatic nuclei, whereas few lining cells displayed disturbed basal membrane infoldings (Fig. 25d).

\section{Morphometric and statistical analysis (Table 1, and Histogram 1)}

The mean area percentage (\%) of collagen fiber content in the energy drink group (Group II) showed a highly significant increase $(37.63 \pm 1.54)$ compared to the control group (10.16 \pm 1.20 ), Moreover, withdrawal group (Group III) showed a significant increase $(18.47 \pm 1.24)$ compared to the control and a significant decrease compared to energy drink group (Group II) .

The color intensity of $\alpha$-SMA positive immunoreaction in the energy drink group (Group II) showed a highly significant increase $(34.92 \pm 3.97)$ compared to the control group (11.86 \pm 1.89 ), while withdrawal group (Group III) showed significant increase $(17.02 \pm 1.31)$ compared to the control and significant decrease compared to energy drink group (Group II).

Table 1: Summarizes the collagen fiber mean area percentage and the color intensity of $\alpha$-SMA immunoreaction (mean \pm standard deviation) for all groups.

\begin{tabular}{|c|c|c|c|}
\hline groups & Group I & Group II & Group III \\
\hline $\begin{array}{l}\text { Collagen-fiber } \\
\text { mean area } \\
\text { percentage }(\%)\end{array}$ & $10.16 \pm 1.20$ & $37.63 \pm 1.54 \mathrm{a}$ & $18.47 \pm 1.24 \mathrm{~b}$ \\
\hline $\begin{array}{l}\alpha \text {-SMA color } \\
\text { intensity }\end{array}$ & $11.86 \pm 1.89$ & $34.92 \pm 3.97 \mathrm{a}$ & $17.02 \pm 1.31 \mathrm{~b}$ \\
\hline
\end{tabular}

a highly significant compared to group I, b significant compared to group II 


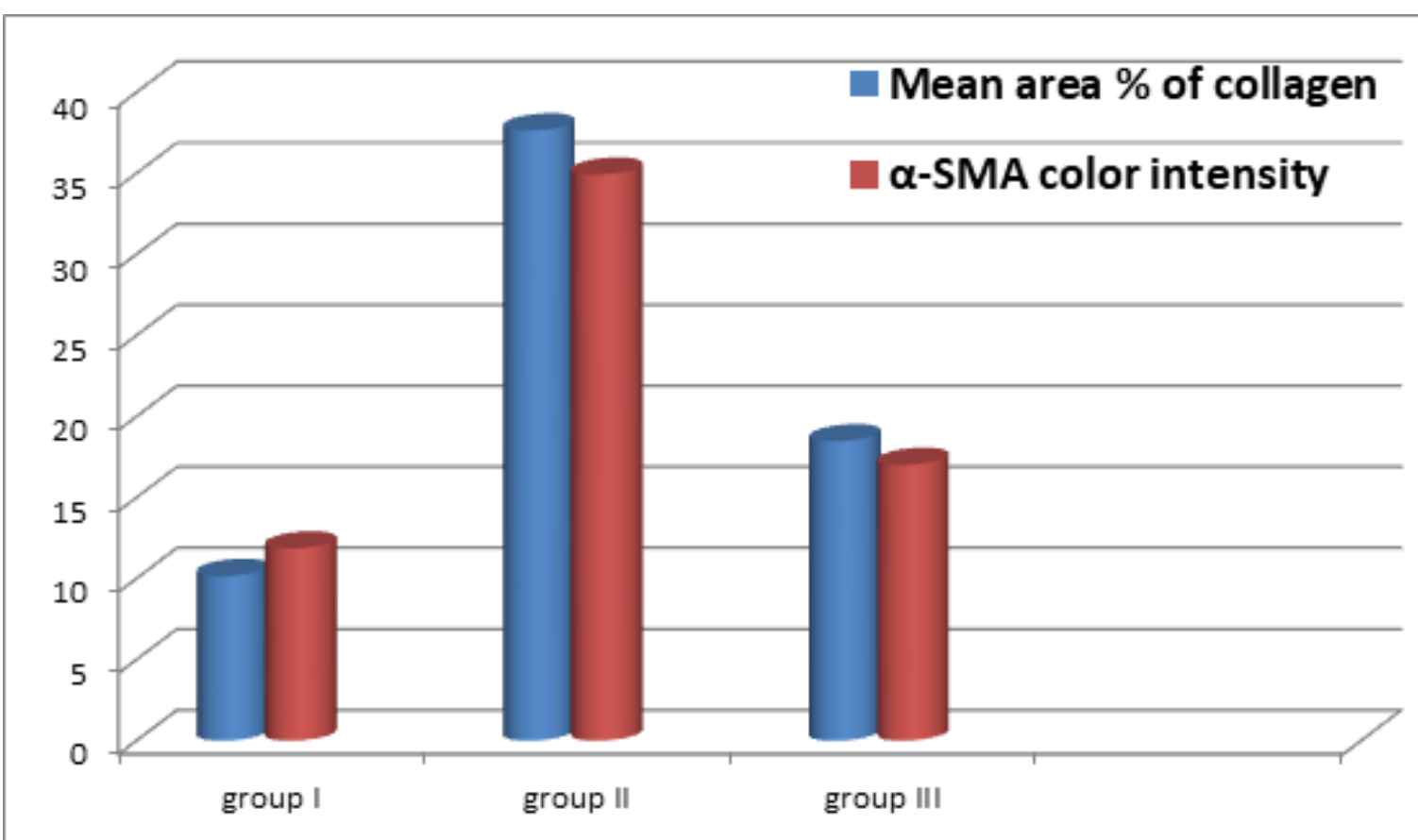

Histogram 1: Showing the mean area percentage of collagen fiber and $\alpha$-SMA color intensity

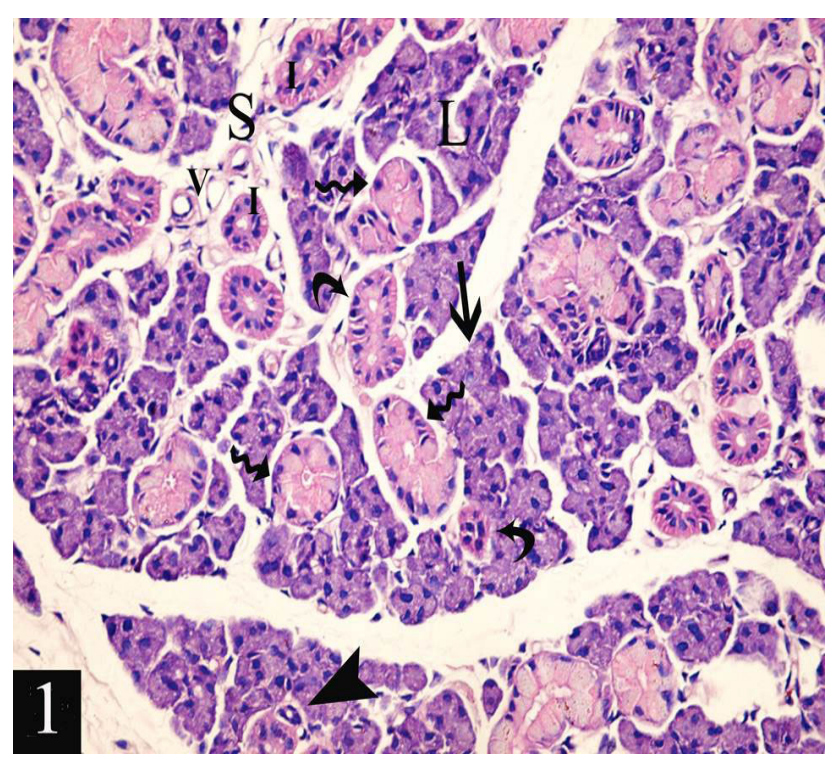

Fig. 1: A photomicrograph of submandibular gland section from control group showing numerous lobules (L) separated by thin connective tissue septa (S) which convey blood vessels (V) and interlobular excretory ducts (I). The lobules show closely packed serous acini (arrow), intercalated (arrow head), striated (curved arrow), and granular convoluted (wavy arrow) ducts.

(H\&E. X400)

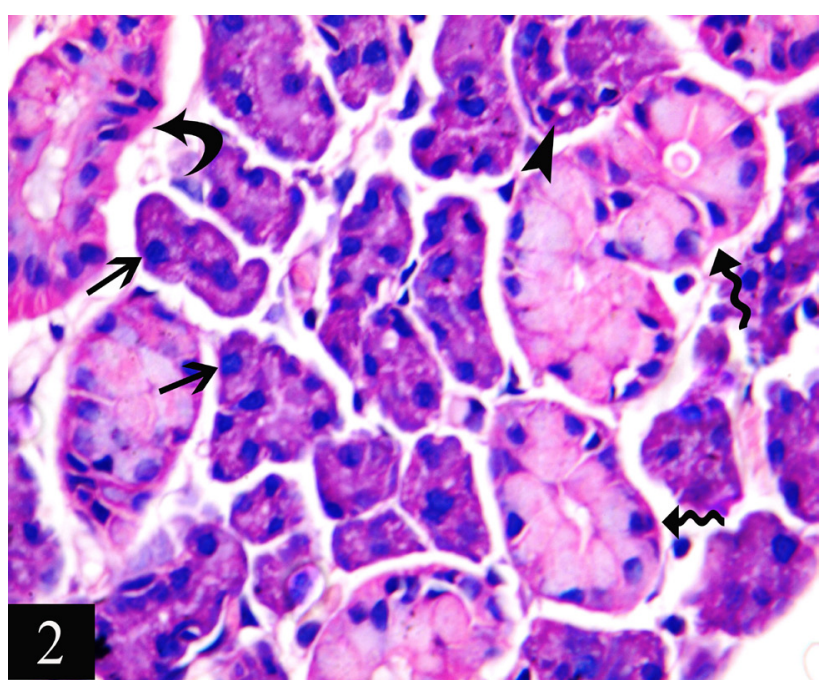

Fig. 2: A photomicrograph of submandibular gland section from control group showing acinar secretory cells having darkly stained cytoplasm and rounded basophilic nuclei (arrow). The intercalated ducts are lined by simple cuboidal epithelium (arrow head). The striated ducts are lined by columnar cells having oval nuclei (curved arrow). The well-developed granular convoluted duct are lined by columnar cells having eosinophilic cytoplasm (wavy arrow).

(H\&E. X1000) 


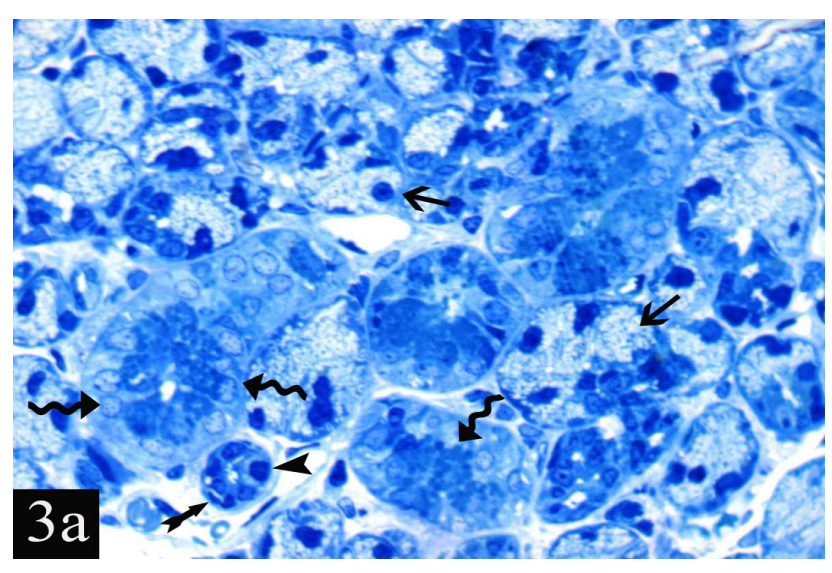

Fig. 3a: Photomicrographs of submandibular gland sections from control group showing: acinar secretory cells with pale-stained granules filling the cytoplasm (arrow) and intercalated duct (arrow head) surrounded by myoepithelial cell (tailed arrow). Cells of the granular convoluted ducts have darkly-stained secretory granules in their apical cytoplasm (wavy arrow)

(Toluidine blue, X1000)

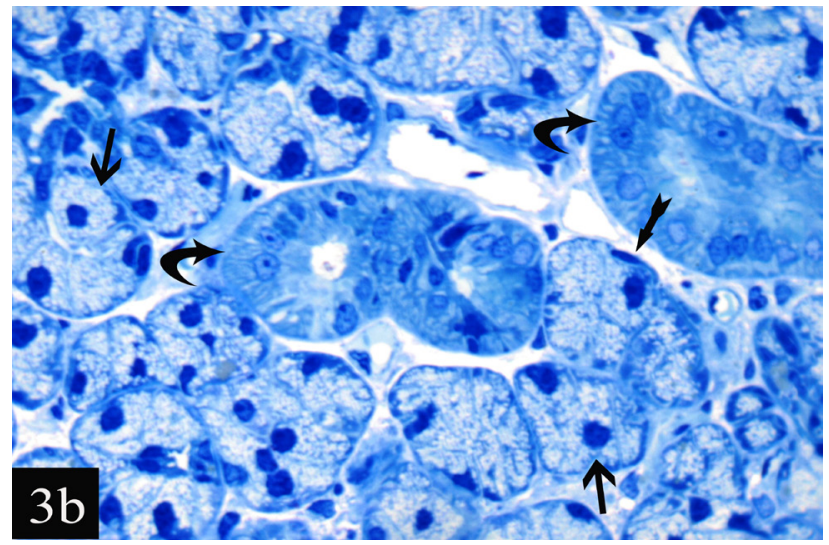

Fig. 3b: Photomicrographs of submandibular gland sections from control group showing acinar secretory cells (arrow) surrounded by myoepithelial cells (tailed arrow) and striated ducts with basal striations (curved arrow).

(Toluidine blue, X1000)

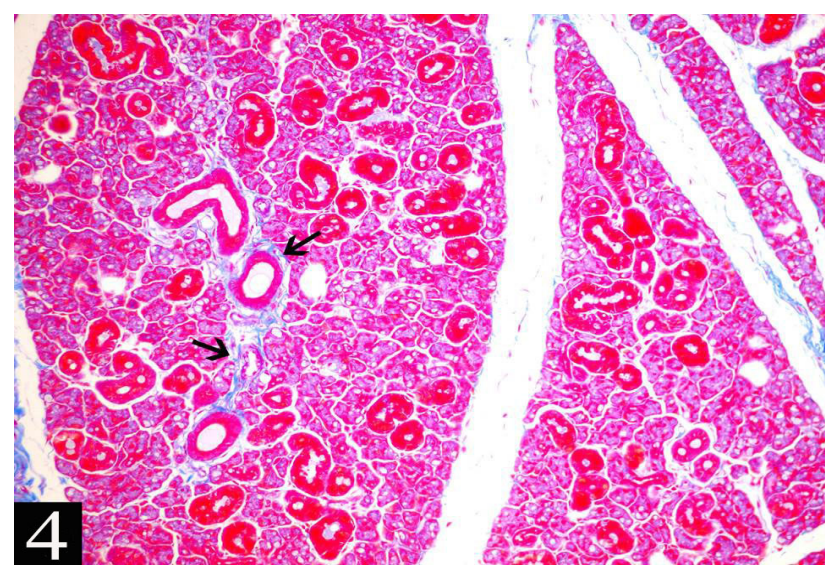

Fig. 4: A photomicrograph of submandibular gland section from control group showing scanty collagen fibers (blue color) in the connective tissue septa between the lobules of the gland surrounding the blood vessels and large excretory ducts (arrow).

(Mallory trichrome, X 200)

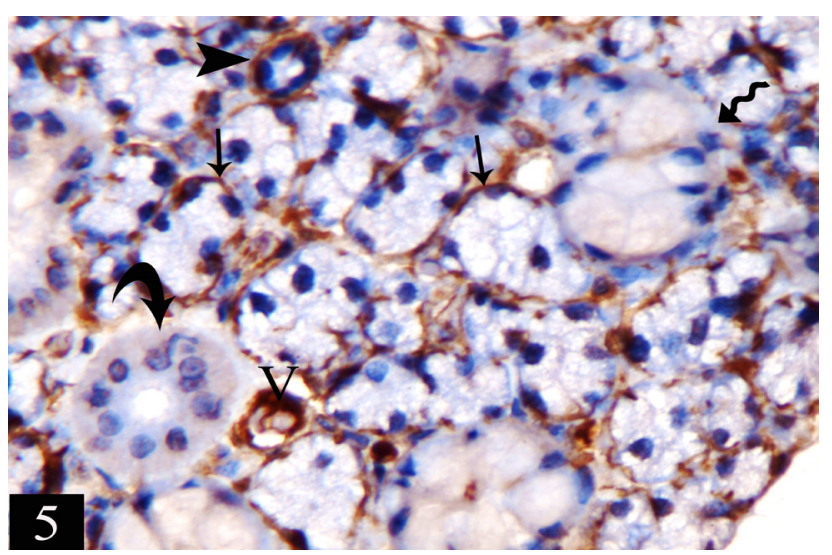

Fig. 5: A photomicrograph of submandibular gland section from control group showing weak positive immunoreaction for $\alpha$-SMA in the cytoplasm of the myoepithelial cells around the acini (arrow) and intercalated duct (arrow head), whereas negative reaction is noticed around the striated duct (curved arrow) and granular duct (wavy arrow). Positive immunoreaction appears in the wall of the blood vessel (V).

( $\alpha$-SMA immunostaining, X1000)

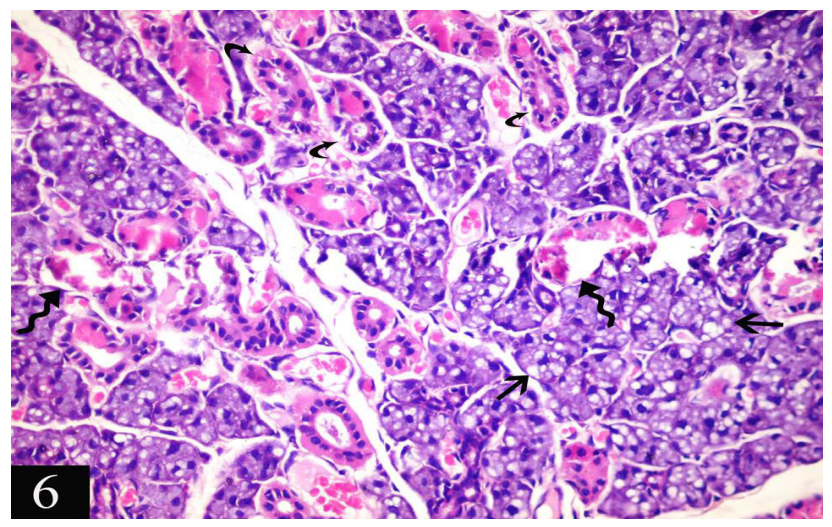

Fig. 6: A photomicrograph of submandibular gland section from energy drink group (Group II) showing cytoplasmic vacuoles of the acinar cells (arrow) and destroyed granular duct cells (wavy arrow). The cells lining of the striated ducts show cytoplasmic vacuoles and disturbed basal cell membrane (curved arrow).

(H\&E. X400)

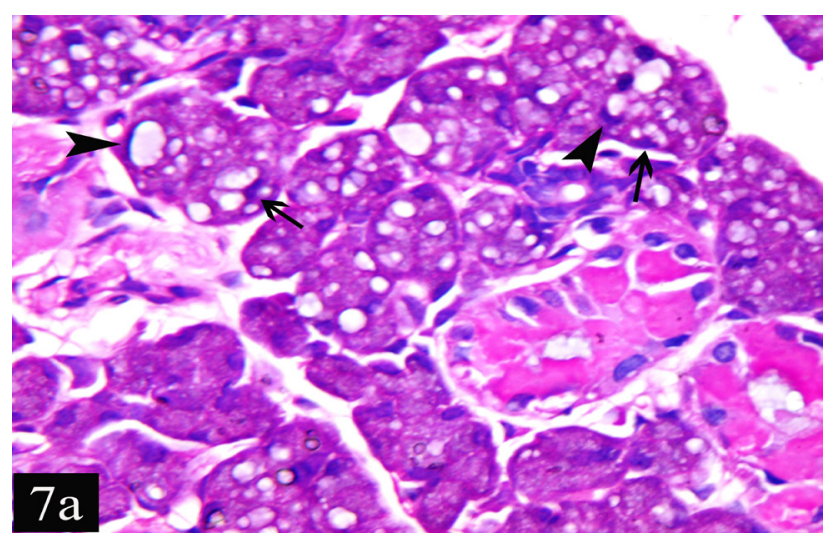

Fig. 7a: Photomicrographs of submandibular gland sections from energy drink group (Group II) showing cytoplasmic vacuoles of the acinar cells with small deeply stained nuclei (arrow) or irregular compressed one (arrow head).

(H\&E.X1000) 


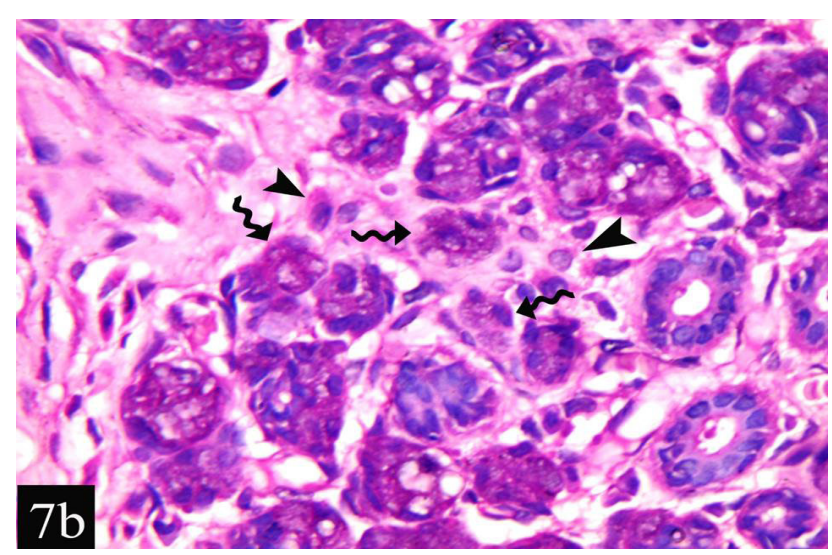

Fig. 7b: Photomicrographs of submandibular gland sections from energy drink group (Group II) showing some shrunken acini (wavy arrow) with infiltrating mononuclear cells inbetween (arrow head).

(H\&E. X1000)

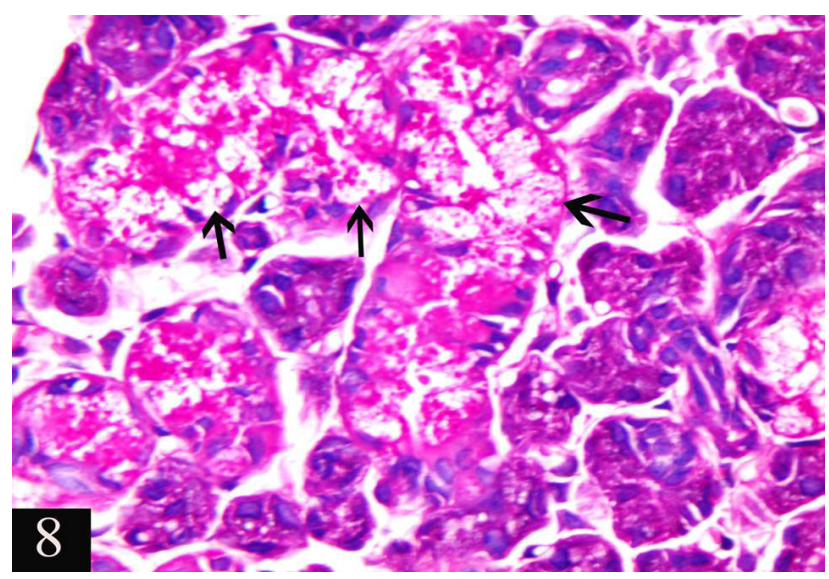

Fig. 8: A photomicrograph of submandibular gland section from energy drink group (Group II) showing reduced acidophilic content of the cytoplasm of granular duct cells (arrow).

(H\&E. X1000)

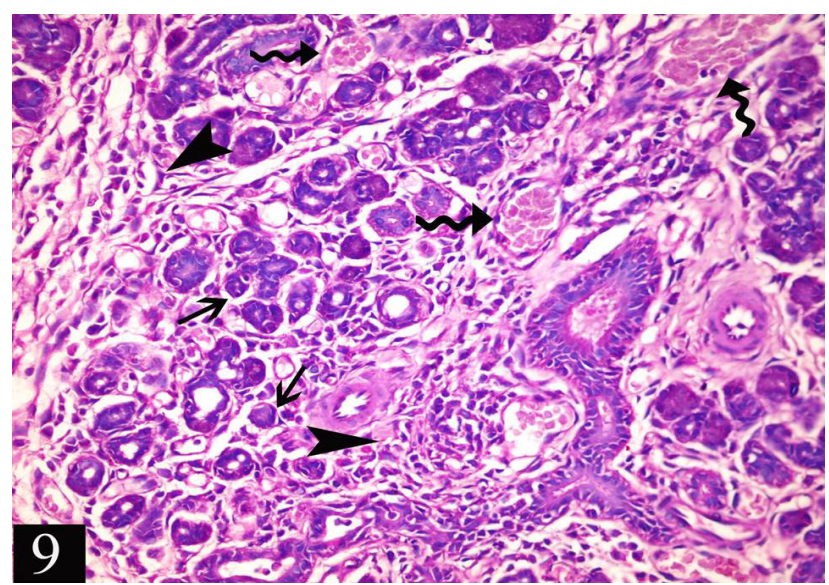

Fig. 9: A photomicrograph of submandibular gland section from energy drink group (Group II) showing numerous mononuclear cellular infiltration (arrow head) and dilated congested blood vessels (wavy arrow) in the connective tissue septa. Notice, some shrunken acini (arrow).

(H\&E. X400)

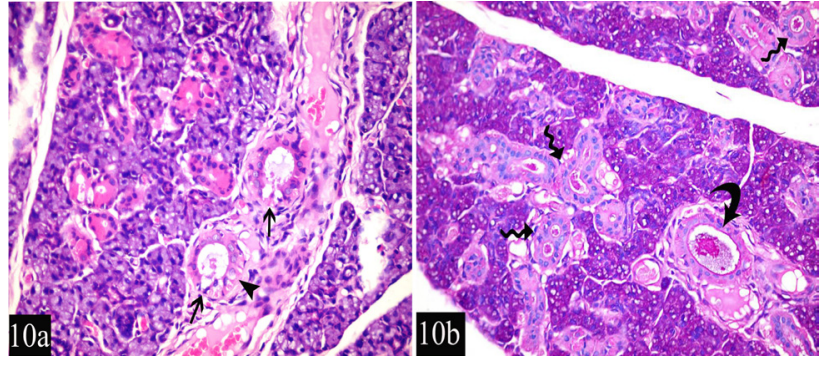

Fig. 10: Photomicrographs of submandibular gland sections from energy drink group (Group II) showing: (a) Dilated interlobular excretory ducts with cytoplasmic vaculation of some lining cells (arrow head) and destroyed other cells (arrow).

(H\&E. X400)

(b) Stagnant salivary secretion in the intralobular ducts (wavy arrow) as well as interlobular excretory ducts (curved arrow).

(H\&E. X400)

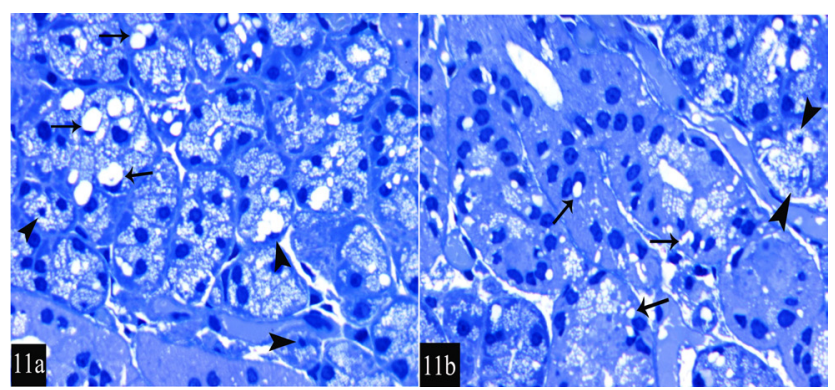

Fig. 11: Photomicrographs of submandibular gland sections from energy drink group (Group II), showing: (a) Some acinar cells with large cytoplasmic vacuoles compressing the nuclei (arrow). Notice small deeply stained nuclei of other acinar cells (arrow head).

(Toluidine blue, X1000)

(b) Some acinar cells with fragmented nuclei (arrow head) and cytoplasmic vacuoles of the striated duct cells (arrow).

(Toluidine blue, X1000)

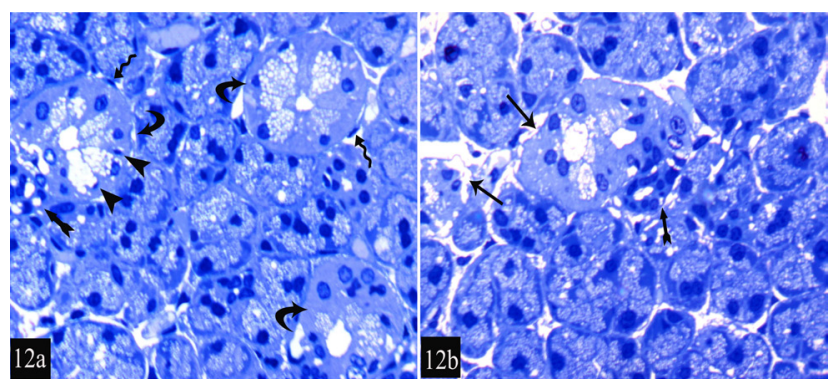

Fig. 12: Photomicrographs of submandibular gland sections from energy drink group (Group II), showing (a) Lining cells of striated ducts with accumulation of numerous lightly stained apical cytoplasmic granules (curved arrow) and small deeply stained nuclei (arrow head). The myoepithelial cells appear around the striated ducts (wavy arrow). Few cytoplasmic vacuoles are seen in lining cells of intercalated ducts (tailed arrow).

(Toluidine blue, X1000)

(b) Lining cells of striated ducts with disturbed basal cell membrane striation (arrow). Few cytoplasmic vacuoles are seen in lining cells of intercalated ducts (tailed arrow).

(Toluidine blue, X1000) 


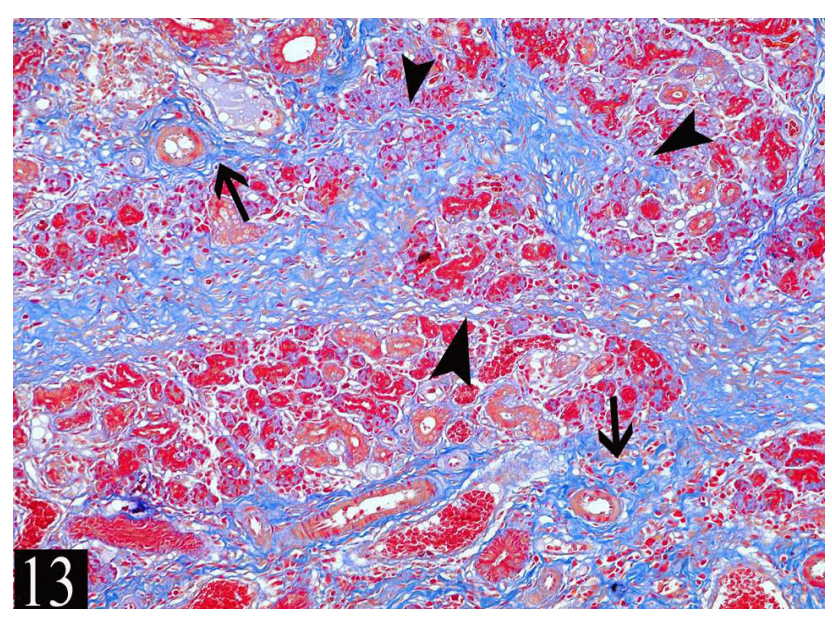

Fig. 13: A photomicrograph of submandibular gland section from energy drink group (Group II) showing deposition of abundant amount of collagen fibers in the connective tissue septa between the lobules (arrow) that extended to surround the intralobular secretory acini and ducts (arrow head).

(Mallory trichrome, X 200)

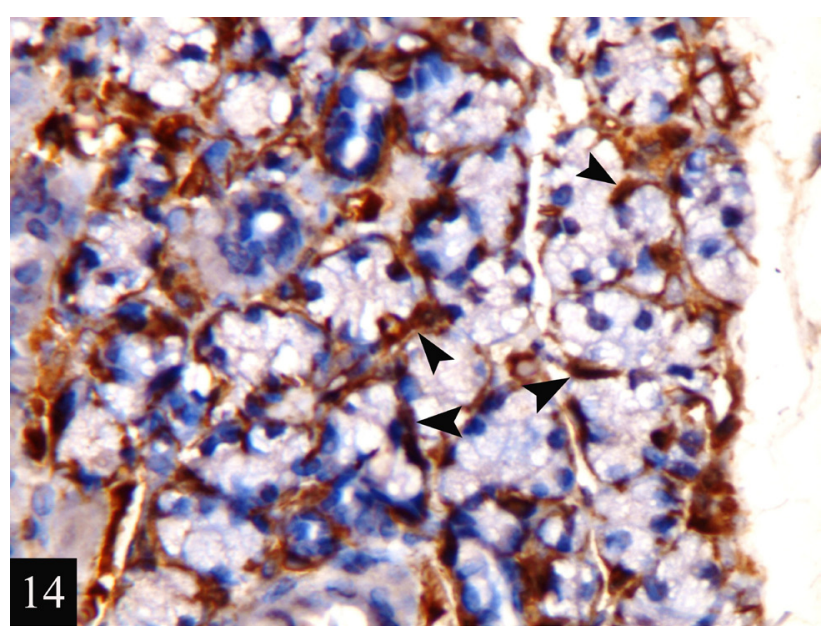

Fig. 14: A photomicrograph of submandibular gland section from energy drink group (Group II) showing a strong positive immunoreaction for $\alpha$-SMA around the acini (arrow head). $(\alpha$-SMA immunostaining, X1000)

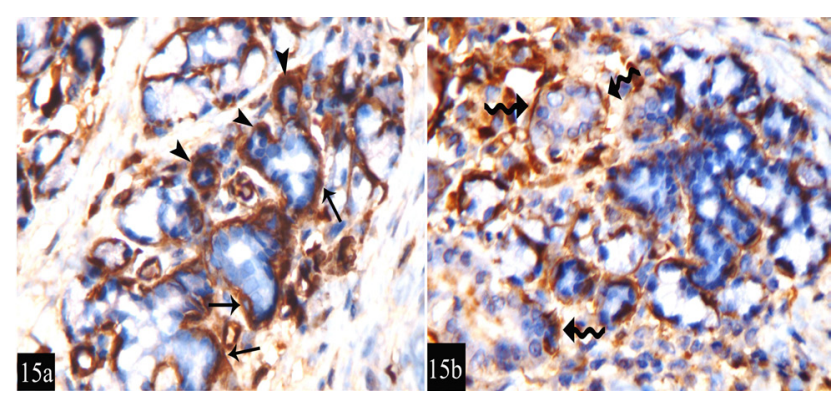

Fig. 15: Photomicrographs of submandibular gland sections from energy drink group (Group II) showing a strong positive immunoreaction for $\alpha$-SMA: (a) Around intercalated ducts (arrow head) and granular convoluted ducts (arrow). (b) Around striated ducts (wavy arrow).

( $\alpha$-SMA immunostaining, X1000)

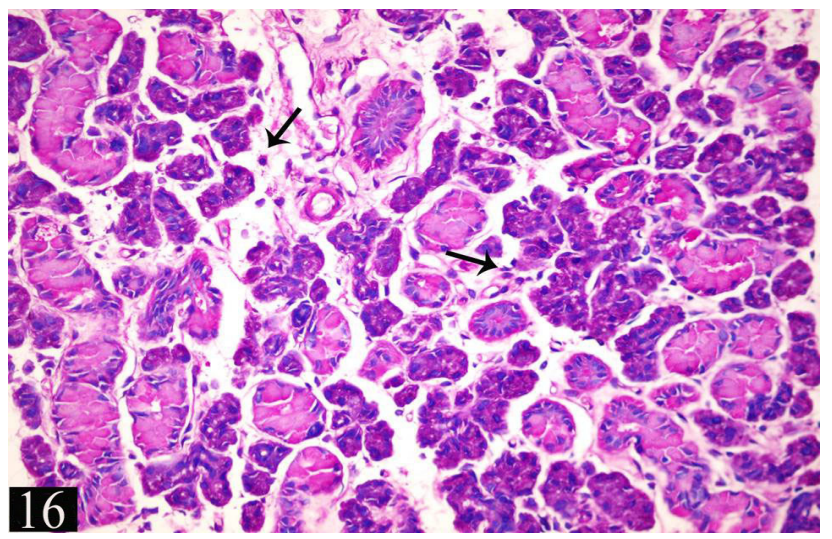

Fig. 16: A photomicrograph of submandibular gland section from withdrawal group (Group III) showing many intralobular acini and ducts appeared more or less as control with few infiltrating mononuclear cells (arrow).

(H\&E, X400)

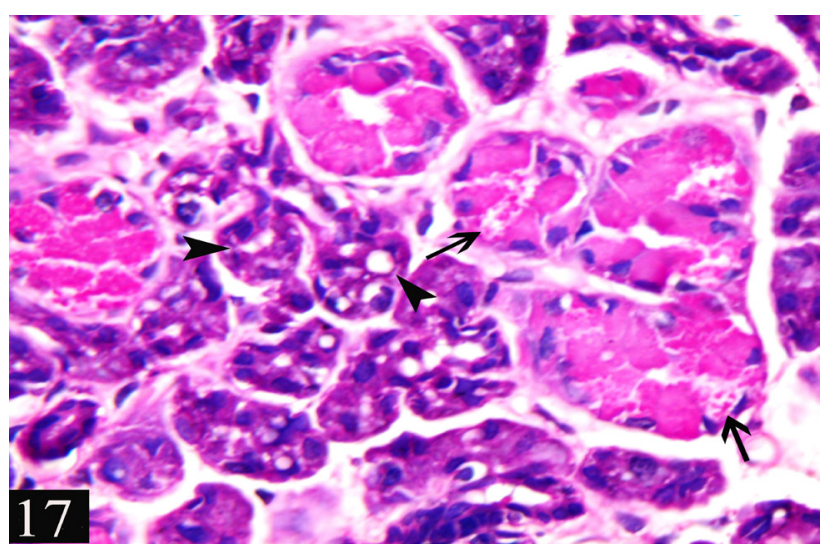

Fig. 17: A photomicrograph of submandibular gland section from withdrawal group (Group III) showing cytoplasmic vacuoles in few acinar cells (arrow head) and reduced acidophilic content of few granular duct cells (arrow).

(H\&E, X1000)

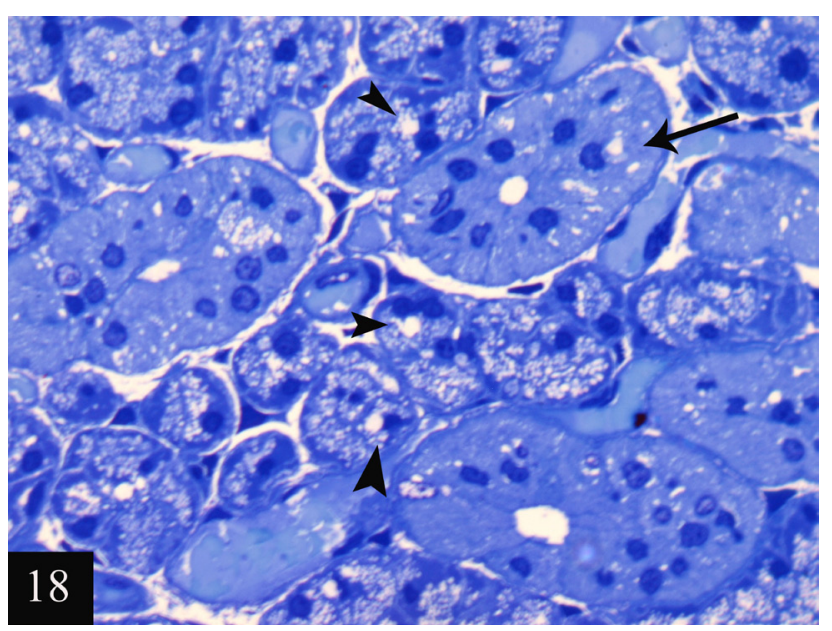

Fig. 18: A photomicrograph of submandibular gland section from withdrawal group (Group III) showing few cytoplasmic vacuoles in few acinar (arrow head) and striated ductal cells (arrow). (Toluidine blue, X1000) 


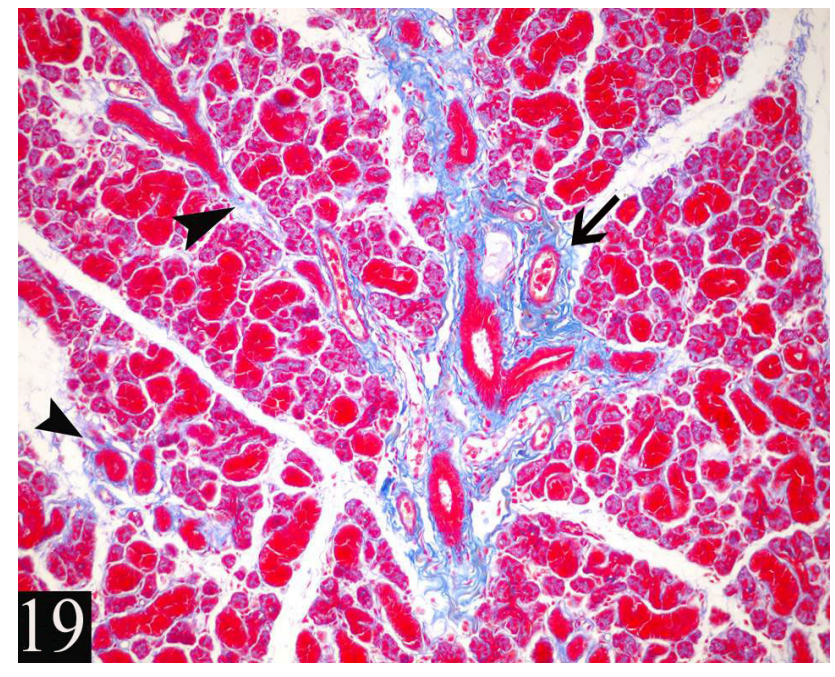

Fig. 19: A photomicrograph of submandibular gland section from withdrawal group (Group III) showing few collagen fibers in connective tissue septa between the lobules (arrow) and around the intralobular acini and ducts (arrow head).

(Mallory trichrome, X 200)

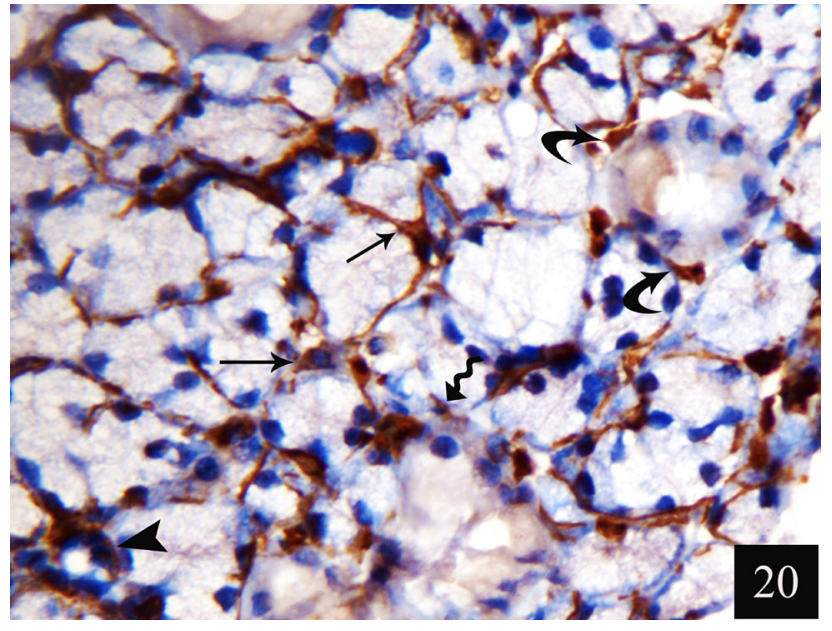

Fig. 20: A photomicrograph of submandibular gland section from withdrawal group (Group III) showing a moderate positive immunoreaction for $\alpha$-SMA around the acini (arrow), intercalated duct (arrow head), striated ducts (curved arrow), and granular duct (wavy arrow).

( $\alpha$-SMA immunostaining, X1000)
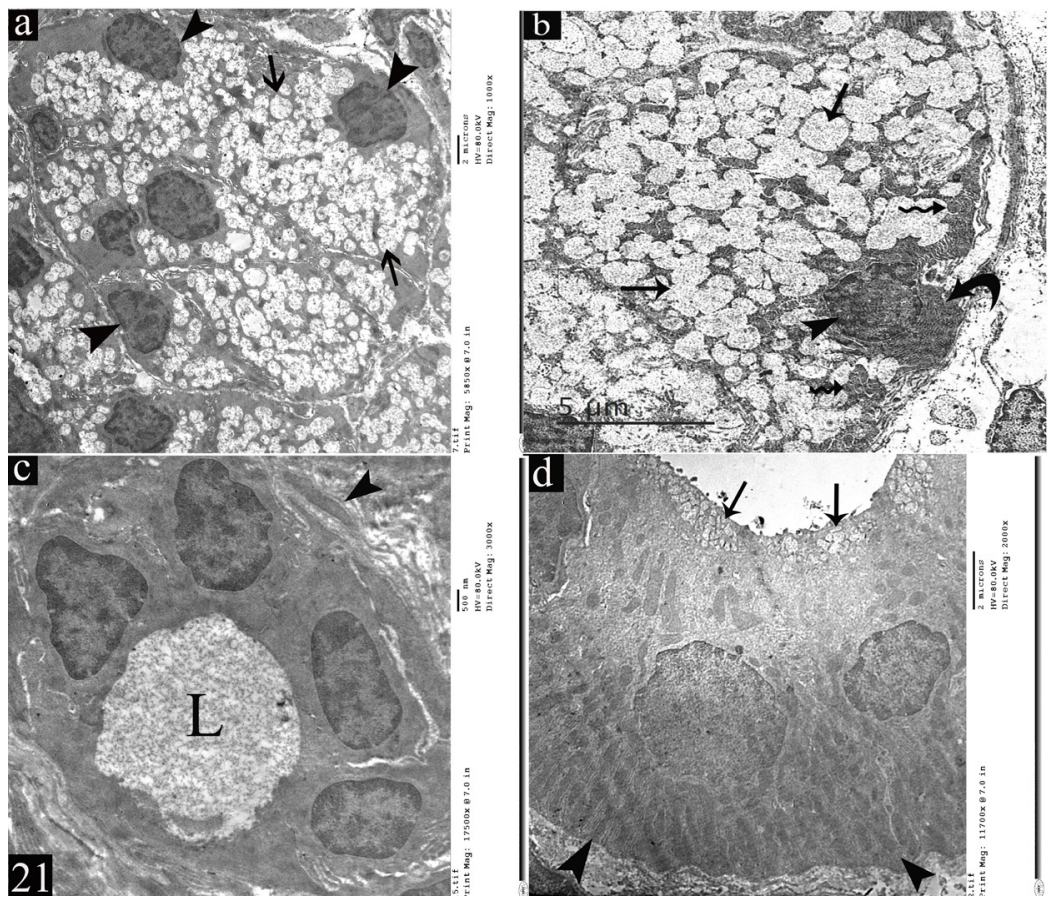

Fig. 21: Electron micrographs of ultrathin sections in submandibular gland from control group showing: (a) Acinar cells having numerous electron lucent secretory granules filling the cytoplasm (arrow) and basal rounded nuclei (arrow head).

(b) Acinar cell with numerous electron lucent secretory granules (arrow), basal rounded nucleus (arrow head), packed parallel cisternae of rough endoplasmic reticulum (curved arrow) and many mitochondria (wavy arrow).

(X 11700)

(c) Intercalated duct lined by simple cubical epithelial cells surrounding central regular rounded lumen (L) and embraced by myoepithelial cells (arrow head).

(X 17500)

(d) Lining cells of a striated duct with numerous mitochondria incorporated within the basal cell membrane infoldings (arrow head). Notice presence of small electron lucent vesicles in their apical cytoplasm (arrow). 

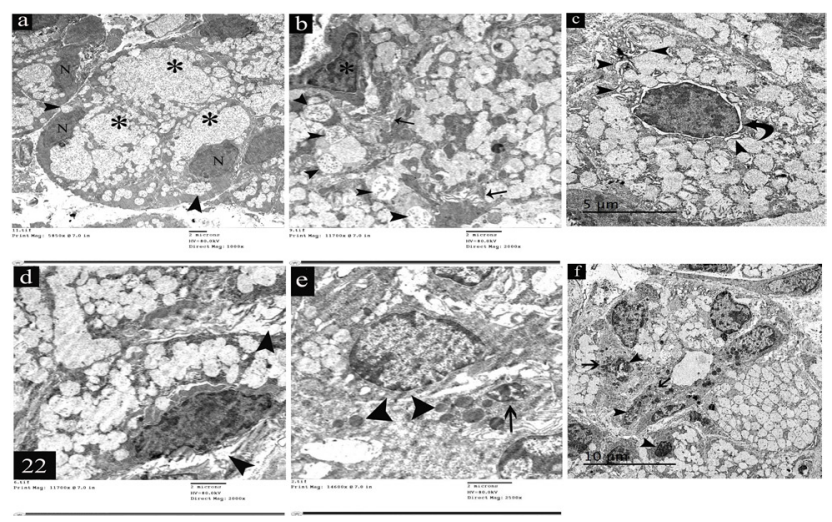

Fig. 22: Electron micrographs of ultrathin sections in submandibular gland from energy drink group (Group II) showing: (a) Acinar cells with fused secretory granules $(*)$ and basal migration of others (arrow head). Notice compression of the nuclei $(\mathrm{N})$.

(X 5850)

(b) Acinar cells have swollen mitochondria with destroyed cristae (arrow head), disorganized and apically dislocated RER (arrow). Notice irregular nucleus $(*)$.

(X 11700)

(c) Acinar cells with dilated RER (arrow head) and dilated perinuclear space (curved arrow).

(X 11700)

(d) Acinar cells with disorganized and fragmented RER (arrow head).

(X 11700)

(e) Acinar cell with accumulated lipid droplets in the cytoplasm (arrow head). Notice shrunken heterochromatic nucleus (arrow).

(X 14600)

(f) Acinar cells with depletion of their secretory granules and numerous electron dense bodies (arrow). Notice small irregular heterochromatic nuclei (arrow head).

(X 5850)
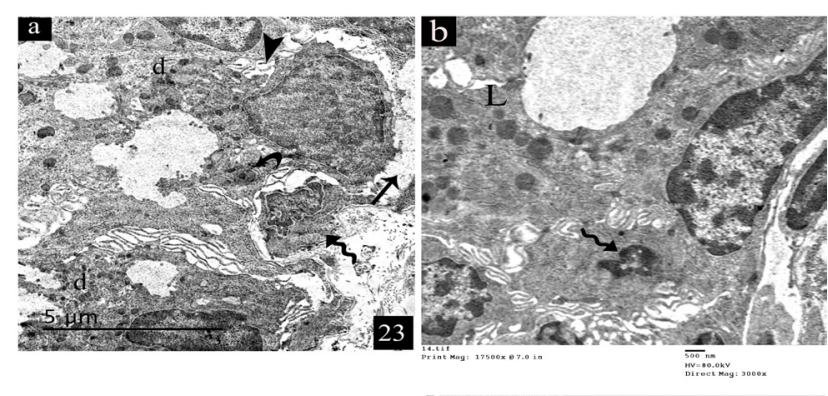

Fig. 23: Electron micrographs of ultrathin sections in submandibular gland from energy drink group (Group II) showing: (a) Intercalated duct with partial separation of their lining cells from the basal lamina (arrow) and widening of the intercellular space (arrow head). Notice shrunken cell with irregular heterochromatic nucleus (wavy arrow), numerous electron dense bodies (d), and lysosomes (curved arrow) in the lining cells.

(X 11700)

(b) Intercalated duct cell having small irregular nucleus with peripheral heterochromatin (wavy arrow). Notice numerous lipid droplets in the cytoplasm of some lining cells (L).

(X 17500)

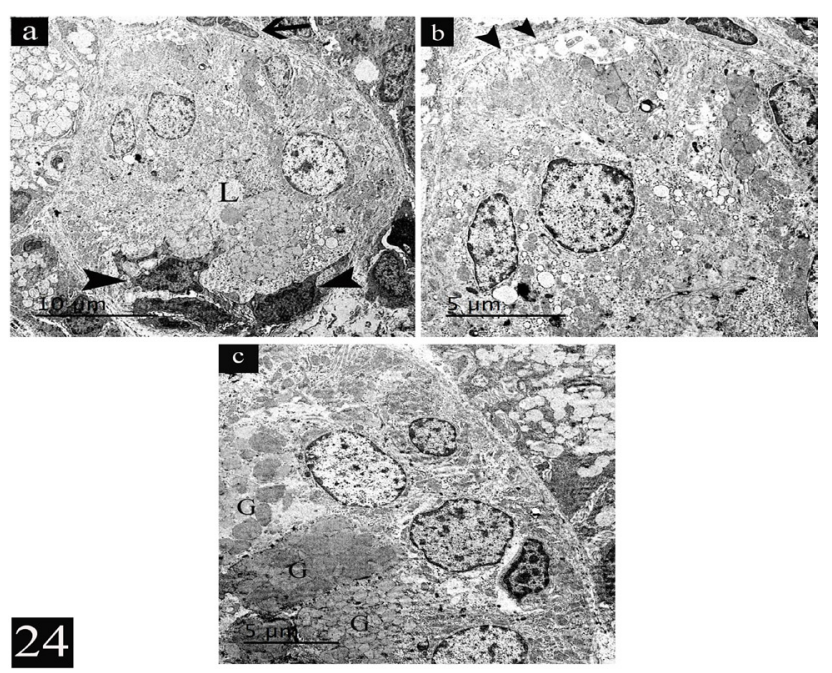

Fig. 24: Electron micrographs of ultrathin sections in submandibular gland from energy drink group (Group II) showing: (a) A striated duct with irregular lumen (L) and a myoepithelial cell (arrow). Notice dark shrunken cells with irregular heterochromatic nuclei (arrow head).

(X 5850)

(b) A higher magnification of some lining cells with disturbed basal membrane infoldings (arrow head).

(X 11700)

(c) Striated duct cells with accumulated secretory granules in their apical cytoplasm $(\mathrm{G})$.

(X 11700)
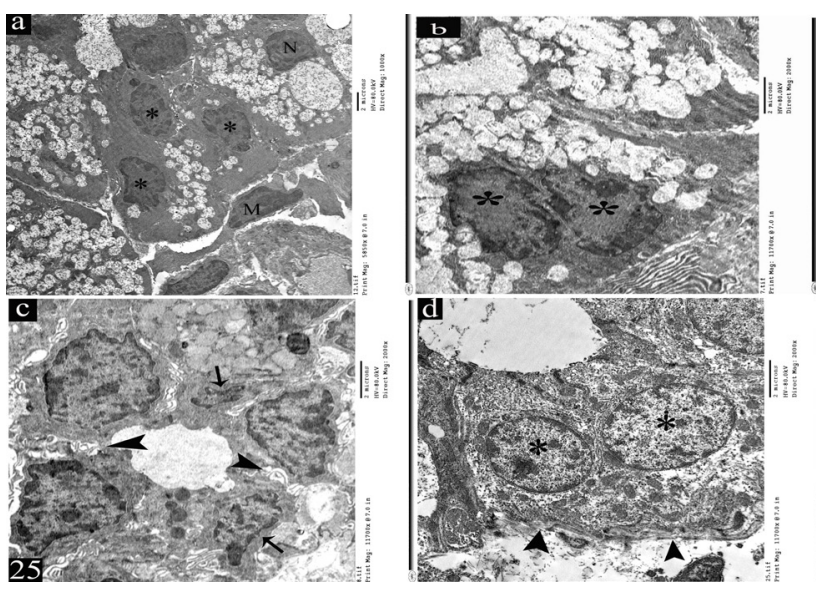

Fig. 25: Electron micrographs of ultrathin sections in submandibular gland from withdrawal group (Group III) showing: (a) Few acinar cells with depletion of their cytoplasmic granules $\left.{ }^{*}\right)$. Others show few large coalescent granules compressing the nucleus $(\mathrm{N})$. Notice, the myoepithelial cell (M).

(X 5850)

(b) Abnormally divided nucleus in the acinar cell (*).

(X 11700)

(c) Intercalated duct with focal separation of the lining cells, mild widening of the intercellular space (arrow head), and few irregular nuclei with peripheral heterochromatin (arrow).

(X 11700)

(d) Striated duct cells with regular euchromatic nuclei $\left(^{*}\right)$ and disturbed basal membrane infoldings (arrow head).

(X 11700) 


\section{DISCUSSION}

In our study, long term consumption of the red bull energy drink induced marked alterations in the normal histological structure of the acinar and ductal cells of the submandibular salivary gland of albino rats. These were in the form of disorganization, destroyed cells, cytoplasmic vacuoles, and irregular compressed or pyknotic nuclei. In withdrawal group, there was amelioration of the induced structural changes which may suggest attempts of recovery to the normal structure.

In agreement with our results, red bull energy drink were found to produce similar structural changes in rat liver, kidney ${ }^{[21,28]}$, hematopoietic system ${ }^{[29]}$, pancreas and stomach ${ }^{[30]}$. Moreover, significant changes in many biochemical parameters have been reported as renal function, liver enzymes, plasma potassium, calcium, plasma triglycerides, and total white blood cell count ${ }^{[23]}$. Prolonged use of this energy drink leads to many side effects such as cardiac arrhythmias, cardiac arrest, and hepatitis. These side effects lead to increased mortality rate among its consumers. The induced structural changes were attributed mostly to the active ingredients present in the red bull energy drink ${ }^{[31-33]}$.

Red bull inhibits A2A adenosine receptors leading to development of interstitial inflammation. This results in changes in organs functions and structure ${ }^{[28]}$. Moreover, it produces a pro-oxidant condition or induces oxidative stress in tissues due to high caffeine content especially in prolonged use. In addition, some antioxidants could alleviate this oxidant effect ${ }^{[30,34,35]}$.

The possible mechanisms involved in red bull inducedoxidative stress are the decrease in tissue sensitivity to insulin, impaired glucose metabolism, and increase in stress hormone secretion. This results in elevated blood glucose, lipolysis, and glucogenesis which are accompanied with decreased glucose consumption peripherally through inhibition of glycolytic enzymes. A hyperglycemic environment results with subsequent glycation of membrane phospholipids of the cell membrane or even the intracellular organelles leading to lipid peroxidation (oxidative stress) and DNA damage in organs. Under oxidative stress state, there was an increase in the production of inducible nitric oxide synthase (iNOS) and reduced glutathione and decrease in production of glutathione peroxidase and superoxide dismutase. This imbalance results in cell damage ${ }^{[30,34,36]}$.

Chronic use of energy drinks leads to an inflammatory response, oxidative stress, and cell death by apoptosis ${ }^{[37]}$. Oxidative stress results in altered secretory protein synthesis and disturbed secretory function in the submandibular salivary gland. As a result, this secretory material accumulates in the cytoplasm of the acinar cells leading to cellular degeneration, atrophy of the cytoplasm and nuclei, and even cell death. This explains the induced structural changes such as widely separated shrunken acini, distortion and loss of some intralobular acini and $\operatorname{ducts}^{[38-40]}$.

The degenerative changes of the acinar and ductal cells were variable. Some acini were swollen with multiple cytoplasmic vacuoles while other acini were degenerated with lysis of their chromatin. This was attributed to fatty degeneration and accumulation of the degenerative products within the cytoplasm. The cell vacuoles may be due to reduced secretory activity of the acinar cells and decrease in the secretory material of the granules ${ }^{[41,42]}$. Moreover, chronic use of energy drinks leads to cytotoxic edema and swelling of the parenchymal cells due to water shift from extracellular space to the cytoplasm. So energy drinks behave as a toxin to parenchymal cells and could affect cellular integrity resulting in disturbed membrane permeability with subsequent changes in homeostasis of cell volume. This occurs as a result of increased rate of catabolism due to high insulin availability caused by sweetening gradients present in energy drinks ${ }^{[43,44]}$.

The most obvious changes in this work are the irregular nuclear outlines and pyknosis that affect acinar and ductal cells as well as disturbed basal membrane infoldings of the striated ducts. These changes were considered as a sign of toxicity and were attributed to the preservatives or caffeine gradient that are present in the red bull energy drinks. Ultrastructurally, there were several changes mainly in acinar cells as swollen disrupted mitochondria, dilatation and fragmentation of RER cisternae as well as nuclear changes. These changes were a manifestation of cell damage and were caused by lipid peroxidation (oxidative stress) and DNA damage due to preservative toxic effects. Mitochondria are more susceptible to toxic agents. If mitochondria damaged, cellular metabolism was affected with further cell damaging effects ${ }^{[21,42,45]}$.

Damaged mitochondria result in adenosine triphosphate ATP depletion with subsequent failure in membrane pump or impaired exocytosis as there was no energy for secretion $^{[46]}$. In addition, the ductal cells have no energy for transport of secretion resulting in duct dilatation and stagnant secretion ${ }^{[47]}$.

In our study, the acinar secretory granules merged forming little lakes that were previously explained as an adaptive mechanism ${ }^{[48]}$.

Presences of numerous electron dense bodies and lysosomes in some of the acinar and ductal cells as well as the inflammatory cells had been attributed to the alteration of structure of cytoskeleton of such cells. Energy drinks produce disruption of actin cytoskeleton of the cells which reflect the possible injury caused by such drinks ${ }^{[28,49]}$.

In this research, secretory granules were accumulated in 
the apical cytoplasm of striated duct lining cellsattributed to oxidative stress and altered cytology of acinar and granular ductal cells which lead to changes in the secretory proteins and disturbed their secretory function ${ }^{[38]}$. Noteworthy, the striated ducts endocytose proteins are secreted by the acinar cells in a very low rate in normal animals, but under certain pathological conditions extensive endocytosis takes place to get rid of the abnormal proteins present in saliva before it reaches the mouth, which is considered as a defense mechanism ${ }^{[50]}$.

Dilated congested blood vessels and mononuclear cellular infiltration seen in this study can be explained by microcirculatory disturbance that may have a role in the gland degeneration ${ }^{[41]}$. Energy drink intake had been associated with many cardiovascular disorders as well as increased platelet aggregation and impaired endothelial function $^{[51,52]}$. These findings were due to different reaction of taurine with caffeine present in the red bull energy drink ${ }^{[53]}$. This stromal inflammation may interrupt the diffusion of parenchymal cells oxygen and nutrients resulting in delay in the process of regeneration by the residual intact parenchymal cells ${ }^{[54]}$.

Excessive collagen deposition was detected in energy drink group and could be attributed to different active ingredients present in these beverages which cause inhibition of $\mathrm{A} 2 \mathrm{~A}$ adenosine receptor that protects normal tissues from inflammatory damage. This results in development of interstitial inflammation and fibrosis ${ }^{[28,55]}$.

In energy drink group, the myoepithelial cells surrounded the remaining acini, intercalated ducts, granular ducts and striated ducts. Under some conditions, the acinar progenitor cells participate in preservation of the ducts resulting in appearance of large ducts with myoepithelial cells ${ }^{[56]}$. In addition, there was a significant increase in the intensity of $\alpha$-SMA immunoreaction compared to control group indicating proliferated or hypertrophied myoepithelial cells, which coincided with Cotronneo et al ${ }^{[57]}$. The increase in the size and number of the myoepithelial cells occurs in the degenerated acini and ducts areas to compensate this degeneration. The myoepithelial cells in the degenerated areas have a function which may be phagocytic or stem cells ${ }^{[38]}$. Moreover, in the gland parenchymal injury, the myoepithelial cells capacity were activated aiming to preserve the secretory function of the cells. This was in line with the coalescence and basal migration of the secretory granules that are seen in this study to increase the secretory capacity of the remaining acinar cells ${ }^{[54]}$.

In withdrawal group, there was a decrease in the intensity of the morphological and ultrastructural changes as well as a significant decrease in the intensity of $\alpha$-SMA immunoreaction as compared to energy drink group. These findings may suggest attempts for gland regeneration after withdrawal of the red bull energy drink.

Abnormal divided nuclei of some acinar cells were observed in this group (division of nucleus without division of the cytoplasm). It was assumed that mononuclear cells undergo endomitosis to duplicate DNA content. These numerous mitotic figures were explained by being an adaptive attempt of the acinar cells to repair after injury ${ }^{[47]}$.

The regeneration of the salivary parenchymal structures is dependent on proliferation of cells of the secretory acini, intercalated duct and myoepithelial cells. Under chronic pathological conditions, active proliferation of myoepithelial cells occurs and the proliferation activity indices elevated two folds in the acinar cells, four folds in intercalated duct lining cells and ten folds in the myoepithelial cells ${ }^{[58,59]}$.

The salivary gland stem and progenitor cells were identified and characterized, whereas, their location was related to ductal, acinar and myoepithelial cells in adults gland These stem or progenitor cells have self-renewal as well as differentiation ability and can replenish the damaged epithelial cells ${ }^{[60,61]}$. So, the submandibular salivary gland showed a compensatory response in intact areas containing stem or progenitor cells after red bull energy drink withdrawal with partial recovery of the normal structure.

\section{CONCLUSION}

The caffeinated energy drink (red bull) induced structural changes in the submandibular salivary glands of adult male albino rats which were partially ameliorated by its withdrawal. So, excessive intake of the caffeinated energy drinks should be considered a health risk for human. Further studies are recommended to evaluate the effect of different doses and durations of this energy drink, besides to evaluate the effect of its withdrawal on different organs.

\section{CONFLICT OF INTEREST}

There are no conflicts of interest.

\section{REFERENCES}

1. Hayat NQ, Tahir M, Munir B, Sami W. 2010. Effect of methimazole-induced hypothyroidism on histological characteristics of parotid gland of albino rat. J Ayub Med Col Abbottabad. 22: $22-27$.

2. Olver IN. 2006. Xerotomia: a common adverse effect of drugs and radiation. Aust Prescr. 29: 97-98.

3. Ayuob NN. 2016. Histological and immunohistochemical study on the possible ameliorating effects of thymoquinone on the 
salivary glands of rats with experimentally induced hypothyroidism. Egypt J of Histol. 39:125-135.

4. Amano $\mathrm{O}$ and Iseki S. 2001. Expression and localization of cell growth factors in the salivary gland: a review. Acta Anat. Nippon. 71: 201-211.

5. Amano O, Mizobe $\mathrm{K}$, Bando $\mathrm{Y}$ and Sakiyama K. 2012. Anatomy and Histology of Rodent and Human Major Salivary Glands. Acta Histochem. Cytochem. 45 (5): 241-250.

6. Tamgadge S, Tamgadge A, Satheesan E, Modak N. 2013. Myoepithelial Cell-A Morphologic Diversity - A Review. Research \& Reviews: A Journal of Dentistry RRJoD. 4 (1): 1-10.

7. Shah AAK, Mulla AF, Mayank M. 2016. Pathophysiology of myoepithelial cells in salivary glands. J Oral Maxillofac Pathol. 20: 480-90.

8. Takahashi S, Shinzato K, Domon T, Yamamoto T, Wakita M. 2004. Mitotic proliferation of myoepithelial cells during regeneration of atrophied rat submandibular gland after duct ligation. J Oral Pathol Med. 33: 430-434.

9. Redder C P, Kandagal V S, Vibhute N, Ingaleshwar PS, Shetty SJ, Ahamad S. 2013. Myoepithelial cells: Current perspectives in salivary gland tumors. Clin Cancer Investig J. 2: 101-5.

10. Mora-Rodriguez R and Pallarés JG. 2014. Performance outcomes and unwanted side effects associated with energy drinks. Nutr Rev. 72 (1):108-20.

11. Abian P, Del Coso J, Salinero JJ, Gallo-Salazar C, Areces F, Ruiz-Vicente D, et al. 2015. The ingestion of a caffeinated energy drink improves jump performance and activity patterns in elite badminton players. J Sports Sci. 33(10): 1042-50.

12. Prins PJ, Goss FL, Nagle EF, Beals K, Robertson RJ, Lovalekar MT, Welton GL. 2016. Energy Drinks Improve Five-Kilometer Running Performance in Recreational Endurance Runners. J Strength Cond Res. 30(11): 2979-2990.

13. Reissing CJ, Strain EC, Griffiths RR. 2009. Caffeinated energy drinks a growing problem. Drug Alc Dep. 99: 1-10.

14. Yunusa L and Ahmed L. 2011. Energy drinks composition and health benefits. Bayero. $\mathrm{J}$ pure App Sci. 4: 186-191.

15. Atfila S and Cakir B. 2011. Energy drink consumption in college students and associated factors. Nutr. 27: 316-322.

16. Campbell B, Wilborn C, La Bounty P, et al. 2013. International Society of Sports Nutrition position stand: energy drinks. J Int Soc Sports Nutr. 10: 1.

17. Clauson KA, Shields KM, McQueen CE, et al. 2003. Safety issues associated with commercially available energy drinks. J Am Pharm Assoc. 48 (3), e55-e63, quiz e64-e7.

18. Grasser EK, Miles-Chan JL, Charrière N, Loonam CR, Dulloo AG, Montani JP. 2016. Energy Drinks and Their Impact on the Cardiovascular System: Potential Mechanisms. Adv Nutr. 7(5): 950-60.

19. Olateju T, Begley J, Green DJ, Kerr D. 2015. Physiological and glycemic responses following acute ingestion of a popular functional drink in patients with type 1 diabetes. Can J Diabetes. 39(1):78-82.

20. Bukhar HM, El-Sawy NA, Header AE. 2012. Biological effect of high energy drink on normal and hyperglycemic rats, Pak J Nutr. 11: 301-309.

21. Khayyat L, Sorour J, Al Rawi M, Essawy A. 2012. histological, ultrastructural and physiological studies on the effect of different kinds of energy drinks on the liver of swiss albino rat. J Ame Sci. 8: 688-697.

22. Worthley MI, Prabhu De Scisco A, Schultz C, Sanders P, Willoughby. 2010. Detrimental effects of energy drink consumption on platelet and endothelial function. Am J Med. 123: 184-187.

23. Ugwuja EI. 2014. Biochemical Effects of Energy Drinks Alone or in Combination with Alcohol in Normal Albino Rats. Advanced Pharmaceutical Bulletin. 4(1): 69-74.

24. Gaertner DJ, Hallman TM, Hankenson FC, Batcherder MA. 2008. Anesthesia and analgesia for laboratory rodents. Anesthesia and analgesia in laboratory animals. 2 nd edition. Academic press, San Diego, CA. Boston. 239-240.

25. Bancroft JD and Gamble M. 2008. Theory and practice of histological techniques. 6th edition, Elsevier health science, Churchill Livingstone. 126-127.

26. Ramos-Vara JA, Kiupel M, Baszler T, Bliven L, Brodersen B, Chelack B, West K, Czub S, etal. 2008. Suggested guidelines for immunohistochemical techniques in veterinary diagnostic laboratories. J 
Vet Diagn Invest. 20: 393-413.

27. Bozzola J and Russe L. 1999. Electron microscopy principles and techniques for biologists. 2nd edition. Jones \& Bartlett Pup. London: Toronto, 16-39.

28. Khayyat L, Essawy A, Sorour J, Al Rawy M. 2014. Impact of some energy drinks on the structure and function of the kidney in wistar albino rats. Life Science Journal. 11(10): 1131-1138.

29. Khayyat LI, Essawy AE, Al Rawy MM, Sorour JM. 2014. Comparative study on the effect of energy drinks on haematopoietic system in wistar albino rats. Journal of Environmental Biology. 35: 883-891.

30. Ayuob N and El-Beshbeishy R. 2016. Impact of an Energy Drink on the Structure of Stomach and Pancreas of Albino Rat: Can Omega-3 Provide a Protection? Plos One. 11(2): e0149191.

31. Crişan M, Munteanu C, Roşioru C, Lang C. 2013. Red bull induces biochemical changes in wistar rat liver. Annals of RSCB. XVIII (2): 118-122.

32. Salinero JJ, Lara B, Abian-Vicen J, GonzalezMilla'n C, Areces F, Gallo-Salazar C, RuizVicente D, Coso JD. 2014. The use of energy drinks in sport: perceived ergogenicity and side effects in male and female athletes. British Journal of nutrition. 112: 1494-1502.

33. Akande IS and Banjoko OA. 2011. Assessment of biochemical effect of power hourse enrgy drink on hepatic, renal and histological functions in Sprague dawely rats. Annu Rev Res Biol. 1: 45-56.

34. Ekaluo UB, Uno UU, Edu NE, Ekpo PB, Etta SE. 2016. Effect of Trévo Dietary Supplement on Caffeine Induced Oxidative Stress in Albino Rat Models. The Pharmaceutical and Chemical Journal. 3(2):92-97.

35. Dias TR, Alves MG, Bernardino RL, Martins AD, Moreira AC, Silva J, et al. 2015. Dosedependent effects of caffeine in human Sertoli cells metabolism and oxidative profile: relevance for male fertility. Toxicology. 328:12-20.

36. Sadowska J. 2012. Evaluation of the effect of consuming an energy drink on the concentration of glucose and triacylglycerols and on fatty tissue deposition. A model study. Acta Sci Pol Technol Aliment. 11(3): 311-8
37. Díaz A, Treviño S, Guevara J, Muñoz-Arenas G, Brambila E, Espinosa B, et al. 2016. Energy drink administration in combination with alcohol causes an inflammatory response and oxidative stress in the hippocampus and temporal cortex of rats. Oxidative Medicine and Cellular Longevity. 2016:1-9.

38. Buyuk B, Parlak SN, Keles ON, Can I, Yetim Z, Toktay E, Selli J, Unal B. 2015. Effects of Diabetes on Post-Menopausal Rat Submandibular Glands: A Histopathological and Stereological Examination. Eurasian J Med. 47(3): 199-207.

39. Noguueira FN, Carvalho AM, Yamaguti PM, Nicolau J. 2005. Antioxidant parameters and peroxidation in salivary glands of STZ induced diabetic rats. Streptozin-induced diabetic rats. ClinicaChimicaActa. 353(1-2): 133-139.

40. Ghada AM El- Gusbi, Mohamed TH Shredah, Abd El-Hafez E Soliman. 2014. Submandibular glands as an evident of the effects of antioxidant on alloxan-induced diabetic rats. World J Med Sci. $11(2) ; 210-216$

41. Mubarak R. 2012. Effect of Red Bull energy drink on Rats' Submandibular salivary glands (Light and Electron microscopic Study). Journal of American Science. 8(1): 366-372.

42. Ibrahim SH. Soliman ME, Yehia NM. 2004. Effect of ciprofloxacin on the submandibular salivary gland of adult male albino rat: A light and electron microscopic study. Egypt J Histol. 27 (2): 339 -354 .

43. Adjene JO, Emojevwe V, Idiapho DE. 2014. Effects of long-term consumption of energy drinks on the body and brain weights of adult Wistar rats. Journal of Experimental and Clinical Anatomy. 13 (1 ): 17-20.

44. Seifert SM, Schaechter JL, Hershorin ER, Lipshultz SE. 2011. Health effects of energy drinks on children, adolescents and young adults. Pediatrics. 127(3): 511-28.

45. Balaban RS, Nemoto SF, Finkel T. 2005. Mitochondria, oxidants and aging. Cell. 120: 483495

46. Halawa AM, Mohamed DG, obeid RF. 2016. Capsaicin induced histological and ultrastructural changes in the submandibular salivary gland of albino rats. Future Dental Journal. 2: 22-27. 
47. Mohamed SS, El-Sakhawy MA, Sheriff H, shredah M. 2015. Effect of aspartame on submandibular salivary glands of adult male albino rats. Life science journal. 12(3): 44-50.

48. Dąbrowska E, Szynaka B, Kulikowska-Karpińska E. 2006. Ultrastructural study of the submandibular gland of the rat after 6-month exposure to cadmium and zinc in drinking water. Advances in Medical Science. 51: 245-249.

49. Shide E and Chandrasekaran V. 2011. The Effects of Energy Drinks on the Structure and Function of Epithelial Cells and Fibroblasts.www. stmarys-ca.edu.

50. Hand A, Coleman R, Mazariegos MR, Lotti LV. 1987. Endocytosis of Proteins by Salivary Gland Duct Cells. Journal of dental research. 66(2): 412-9.

51. Grasser EK, Yepuri G, Dulloo AG, Montani J. 2014. Cardio- and cerebrovascular responses to the energy drink Red Bull in young adults: a randomized cross-over study. Eur $\mathbf{J}$ Nutr. 53: 1561-1571.

52. Higgins JP, Tuttle TD, Higgins CL. 2010. Energy beverages: content and safety. Mayo Clin Proc. 85: 1033-1041.

53. Berger AJ and Alford K. 2009. Cardiac arrest in a young man following excess consumption of caffeinated "energy drinks". Med JAust. 190 (1): 41-43.

54. Redman RS. 2008. On approaches to the functional restoration of salivary glands damaged by radiation therapy for head and neck cancer with a review of related aspects of salivary gland morphology and development. Biotech Histochem. 83: 103-130.

55. Tek M, Toptas O, Akkas I, Kazancioglu HO, Firat T, Ezirganli S, Ozan F. 2014. Effects of Energy Drinks on Soft Tissue Healing. J Craniofac Surg. 25: 1-5.

56. Ogawa Y. 2003. Immunohistochemistry of myoepithelial cells in the salivary glands. Orog Histochem Cytochem. 38: 343-426.

57. Cotroneo E, Proctor GB, Paterson KL, Carpenter GH. 2008. Early markers of regeneration following ductal ligation in the rat submandibular gland. Cell Tissue Research. 332: 227-235.

58. Ihrler S, Blasenbreu VS, Sendelhofert A, Rossle M, Harrison JD, Lohrs U. 2004. Regeneration in chronin sialadenitis: an analysis of proliferation and apoptosis based on double immunohistochemical labeling. Virchows Arch. 444: 356-361.

59. Kujan O, Othman R, Alshehri M, Iqbal F, Kochaji N. 2015. Proliferative Activity of Myoepithelial Cells in Irradiated Rabbit Parotid and Submandibular Salivary Glands. J Int Oral Health. 7(2):1-5.

60. Holmberg KV and Hoffman MP. 2014. Anatomy, Biogenesis and Regeneration of Salivary Glands. In Ligtenberg AJM, Veerman ECI (eds): Saliva: Secretion and Functions. Monogr Oral Sci. Basel, Karger. 24: 1-13.

61. Pringle S, Os RV, Coppes RP. 2013. Concise Review: Adult Salivary Gland Stem Cells and a Potential Therapy for Xerostomia. STEM CELLS. 31: 613-619. 


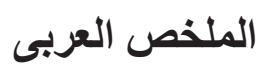

تأثير مشروب طاقة بالكافيين وسحبه على الغدة اللعابية تحث الفكية لذكور الجرذان البيضاء البالغة: دراسة نسيجية ونسيجية مناعية

\section{أميزة عدلى كساب ، صديقة محمد توفيق

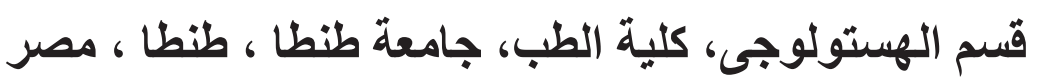

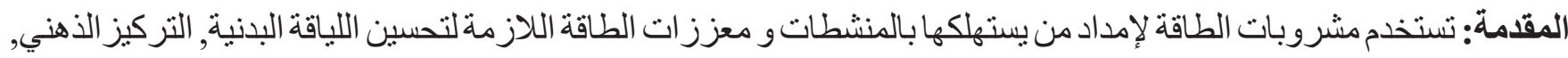

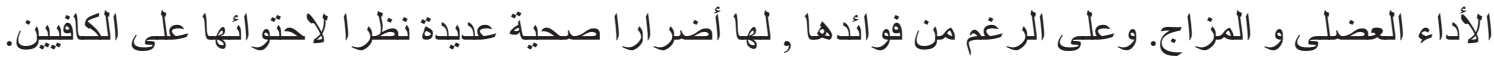
الهذف من البحث: دراسة لتأثير مشروب طاقة بالكافيين على التركيب النسيجى للغذة اللعابية تحت الفكية للجرذان البيضاء وتقييم تأثير سحبه البن.

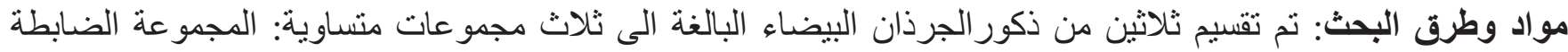

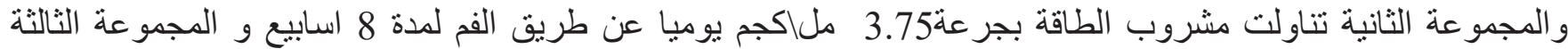

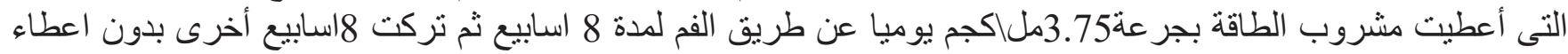

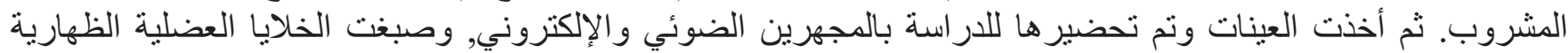
بو اسطة تقنية هستو كيميائية مناعية باستخدام أجسام مضادة لأنيات أكتين العضلات الملساء.

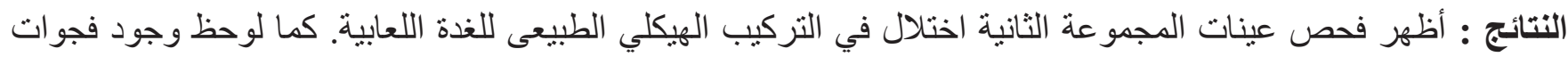

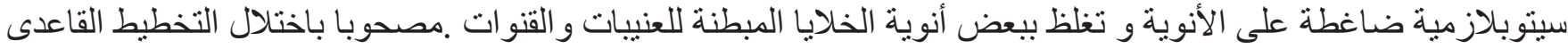

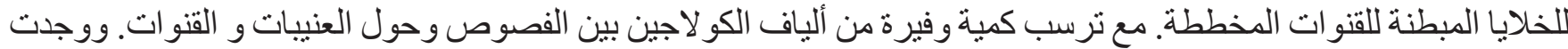

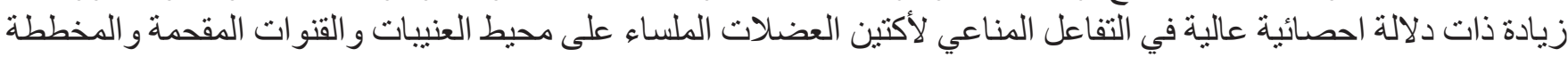

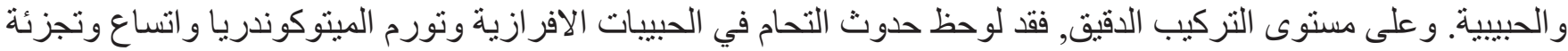

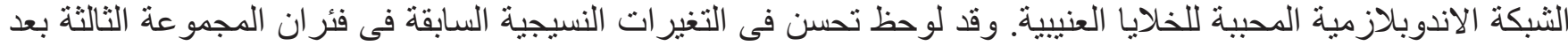
إيقاف تناول مشروب الطاقة المزود بالكافيين. الإستنتاج : سبب مشروب الطاقة بالكافيين فى إحداث تغير ات تركيبية بالغدة اللعابية تحت الفكية للجرذان البران البيضاء و التىى تحسنت

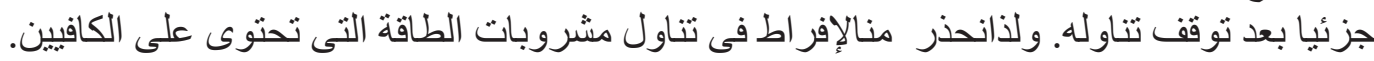

